УДК 631.811.98:632.954:633.16

(C) 2012

Білоножко В. Я., Карпенко В. П., доктори сільськогосподарських наук,

Полторецький С. П., Притуляк Р. М., кандидати сільськогосподарських наук

Уманський національний університет садівництва

\title{
ФІЗІОЛОГО-БІОХІМІЧНІ ПРОЦЕСИ В РОСЛИНАХ ЯЧМЕНЮ ЯРОГО ЗА РОЗДІЛЬНОГО ТА ІНТЕГРОВАНОГО ЗАСТОСУВАННЯ ГЕРБІЦИДІВ І РЕГУЛЯТОРІВ РОСТУ РОСЛИН
}

\section{Рецензент - доктор сільськогосподарських наук, професор Г. П. Жемела}

\begin{abstract}
Наведено узагальнені результати багаторічних досліджень із вивчення дії гербіиидів класів сульфонілсечовини (Гранстар 75, Калібр 75, Хармоні 75), феноксикарбоксилових кислот (2,4-ДА 500, Дікопур Ф 600) і комбінованих препаратів (Лінтур $70 \mathrm{WG}$ ), внесених роздільно та в поєднанні з рістрегуляторами (Емістим C, Атат-25K і Агростимулін), на проходження основних фізіолого-біохімічних прочесів у рослинах ячменю ярого, щуо визначають формування продуктивності посівів.
\end{abstract}

Ключові слова: фізіолого-біохімічні прочеси, гербіциди, регулятори росту рослин, ячмінь ярий.

Постановка проблеми. Гербіциди, як фізіологічно активні речовини, в переважній більшості випадків здатні значно впливати на проходження життєво важливих процесів у рослинному організмі. При цьому не виключена можливість їх акумулювання в товарній продукції та об'єктах навколишнього природного середовища [9]. Тому в усьому світі, а в останні роки і в Україні, ведеться розробка технологій переходу від традиційного до органічного землеробства. Проте, як показує практика більшості країн світових лідерів із виробництва сільськогосподарської продукції, перехід до органічного землеробства призводить до різкого зростання забур'яненості посівів та зниження врожайності ячменю й кукурудзи на $58 \%$, пшениці - на 54 , а сої - на $62 \%[1,7]$. Тому нині, коли в багатьох країнах світу простежується дефіцит продуктів харчування, повністю відмовитися від використання гербіцидів неможливо. Водночас необхідно вести пошук шляхів зниження негативного впливу хімічних сполук гербіцидної дії на агроценози. Однозначно такі технології повинні включати елементи біологізації, що у випадку 3 гербіцидами може бути досягнуто за рахунок інтегрованого їх застосування $з$ регуляторами росту рослин природного походження, що характеризуються антистресовими й імуностимулюючими властивостями [13]. Однак чимало питань стосовно сумісної дії гербіцидів і рістрегуляторів у сумішах вивчені недостатньо. Вибір і оцінка оптимального поєднання препаратів у сумішах, передусім багатокомпонентних, проводиться без урахування особливостей їхньої дії на ключові фізіологічні реакції в рослинному організмі. Тому не 3'ясованими залишаються питання спрямованості дії сумішей гербіцидів і рістрегуляторів на проходження основних фізіологобіохімічних процесів у рослинах, які лежать в основі формування продуктивності посівів.

Аналіз основних досліджень і публікацій, у яких започатковано розв'язання проблеми. Широкомасштабне використання у сільськогосподарському виробництві біологічно активних речовин розпочалося після 1941 р., коли І. Покорним було відкрито сполуку надзвичайно високої фітотоксичності - 2,4-дихлорфеноксиоцтову, а пізніше - 2-метил-4-хлорфеноксиоцтову і 2,4,5трихлорфеноксиоцтову кислоти. Фактично 3 того часу хімічний метод боротьби з бур'янами отримав загальне визнання [17].

Одночасно із впровадженням у виробництво речовин гербіцидної дії вченими розпочинаються всебічні дослідження механізму дії цих сполук на рослинні організми - діяльність ферментів, фотосинтез, транспірацію, дихання, вуглеводний, азотний і фосфорний обміни, морфологічну й анатомічну будову рослин.

У результаті виконаних експериментів учені дійшли висновку, що гербіциди здатні суттєво порушувати обмін речовин не тільки в бур'янів, які $\epsilon$ причиною їх загибелі, але й значно впливають на проходження обмінних процесів у культурних рослинах.

У цей же час встановлюються факти негативної дії препаратів на фізіолого-біохімічні процеси в рослинах, мікробіологічні - в грунті, формування рослинами врожаю та його якісних показників (наявність залишків препаратів).

Весь цей комплекс питань спонукав учених до розробки концепції зменшення негативної дії гербіцидів на культурні рослини, грунт і навко- 
лишнє природне середовище, першим напрямом реалізації якої стало запровадження інтегрованих систем захисту сільськогосподарських культур від шкідливих організмів. Другий напрям зумовив пошук шляхів синтезу малотоксичних препаративних форм гербіцидів, із-поміж яких нині виділяють сполуки класу сульфонілсечовини. Вони мають низькі норми витрати, відзначаються високою селективністю, швидко розкладаються в грунті, малотоксичні для людини, комах і тварин [16].

Реалізація третього напряму передбачала створення комплексів препаратів із кількох діючих речовин або комбінованих препаративних форм. Такі комплекси із кількох діючих речовин забезпечують підвищення активності й селективності препаратів за одночасного зниження рівня надходження їх в екосистеми [11].

Четвертий напрям розпочав свою реалізацію в середині 90-х років минулого століття і триває донині. Він передбачає поєднане використання гербіцидів у комплексі з біологічними рістрегулюючими речовинами (регуляторами росту рослин, мікробіологічними препаратами із рістстимулювальними властивостями тощо), які вперше 3'явилися на ринку України й почали активно впроваджуватись у виробництво. Однак, незважаючи на виняткове значення проблеми сумісного застосування гербіцидів із регуляторами росту рослин, у науковій літературі зустрічаються лише поодинокі роботи, метою яких було 3'ясування біологічних механізмів їх дії [14].

Зважаючи на це, питання інтегрованого застосування гербіцидів із біологічними препаратами потребує наразі активного вивчення. Зокрема, необхідно підвищити рівень теоретичних знань про вплив даних сумішей на проходження фізіолого-біохімічних та інших життєво важливих процесів у рослинних організмах, що дасть можливість цілеспрямовано керувати їх життєдіяльністю в агроценозах.

Мета і завдання. Метою роботи було розкриття особливостей дії гербіцидів різних хімічних класів за роздільного та інтегрованого їх застосування iз рістрегуляторами на проходження фізіолого-біохімічних процесів у рослинах ячменю ярого, які лежать в основі формування продуктивності посівів.

Матеріали і методи досліджень. Дослідження виконували впродовж 1999-2009 рр. у польових та лабораторних умовах кафедри біології Уманського національного університету садівництва (УНУС).

У дослідах вивчали гербіциди, які, згідно 3 прийнятою класифікацією, відносять до наступних хімічних класів: сульфонілсечовини (інгібітори ALS) - Гранстар 75, в. г. (10-25 г/га); Калібр 75, в. г. (30-70 г/га); Хармоні 75, в. г. (520 г/га); феноксикарбоксилові кислоти (синтетичні ауксини) - 2,4-ДА 500, в. р. (1,0 л/га); Дікопур $\Phi 600$, в. p. (0,5-1,5 л/га) та комбіновані препарати - Лінтур 70 WG, в. г. (90-140 г/га). Досліджувані гербіциди вносили в різних нормах окремо і в поєднанні з регуляторами росту рослин Емістим С (5-10 мл/га), Агростимулін (10 мл/га) і мікробіологічним препаратом із рістстимулювальними властивостями Агат-25K (20 г/га). Польові досліди закладали у відповідності із загальноприйнятими вимогами [10] на сортах ячменю ярого Рось, Звершення, Соборний, вегетаційні - 3 дотриманням вимог вегетаційного методу [8].

У процесі досліджень у рослинах вивчали: інтенсивність проходження реакцій пероксидного окиснення ліпідів [15]; вміст у листках рослин антиоксидантів - глутатіону та аскорбату [4, 18], а також хлорофілів $a$ і $b$, суми хлорофілів $(a+b)$, каротиноїдів та активність хлорофілази [2]; вміст водорозчинних цукрів [3]; фотосинтетичну продуктивність хлорофілу [5] та фотосинтетичну продуктивність посівів [12]. Статистичну обробку результатів досліджень проводили за методами дисперсійного та кореляційного аналізів [6].

Результати досліджень. У результаті узагальнення проведених лабораторних, вегетаційних і польових досліджень встановлено, що гербіциди різних хімічних класів, внесені окремо та в поєднанні з регуляторами росту рослин, значно впливають на спрямованість проходження обмінних процесів у рослинах ячменю ярого. Зокрема встановлено, що із наростанням норм внесення досліджуваних гербіцидів без регуляторів росту (наприклад, Калібру 75 до 70 г/га) у листках ячменю ярого на третю добу простежується інтенсифікація генерування активних форм кисню, що зумовлюють розвиток у рослин оксидативного стресу, наслідком якого є підвищений рівень пероксидного окиснення ліпідів (рис. 1).

На десяту добу внесення препаратів рівень пероксидного окиснення ліпідів у рослинах ячменю ярого продовжував зростати, що пов'язано з активізацією ростових та обмінних процесів (перехід рослин до фази кущіння), невід'ємним продуктом яких $\epsilon$ активні форми кисню. Однак у варіантах досліду, де гербіциди застосовували сумісно з регуляторами росту, рівень пероксидного окиснення ліпідів по відношенню до відповідних варіантів без рістрегуляторів знижувався у середньому на 10-25 \%. 


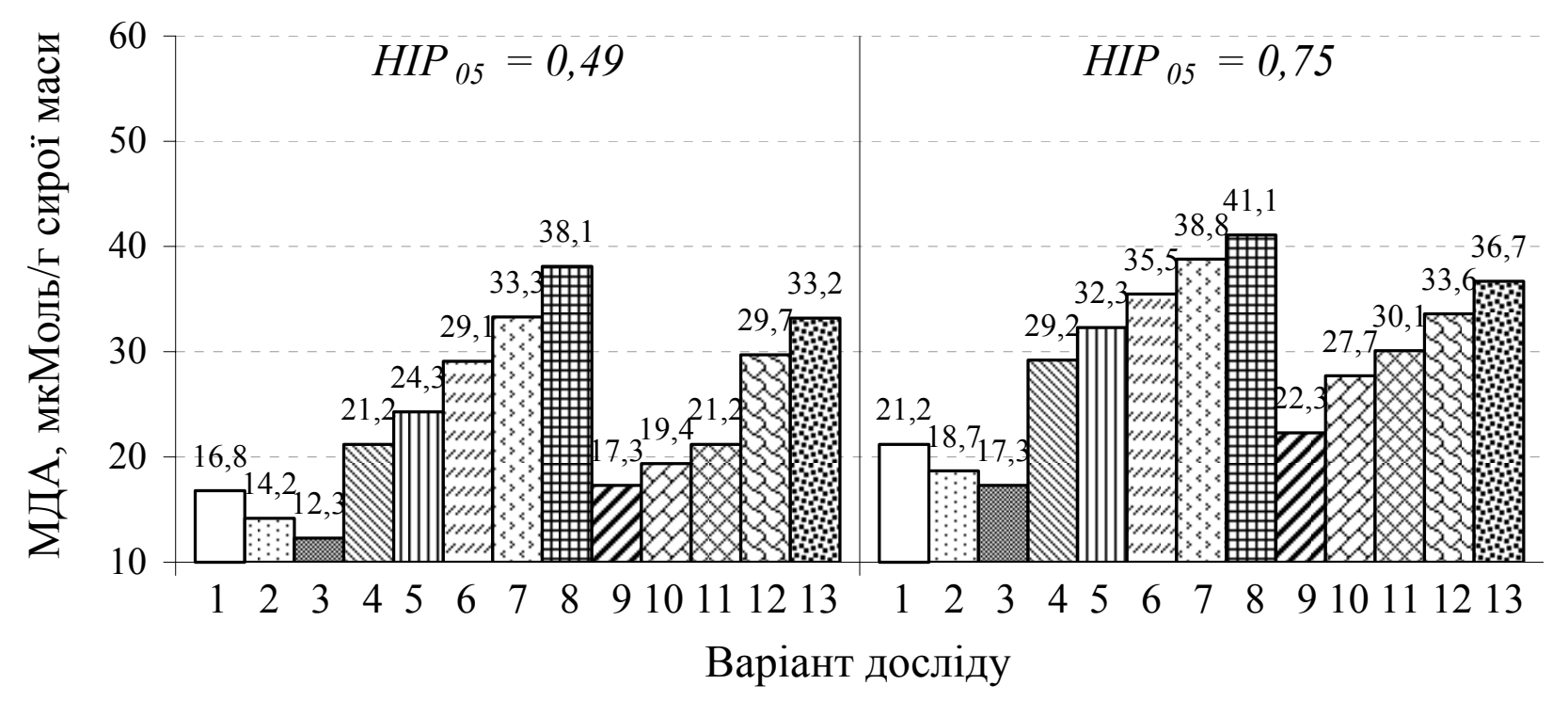

На третю добу На десяту добу

Рис. 1. Вплив різних норм гербіциду Калібр 75, внесених окремо і в поєднанні з Агатом-25К і Агростимуліном, на пероксидне окиснення ліпідів у листках ячменю ярого (вететаційний досліб, 2007 р.):

1. Обробка водою (контроль); 2. Атат-25К; 3. Агростимулін; 4. Калібр 75 -30 г/га; 5. Калібр 75 40 г/га; 6. Калібр 75 - 50 г/га; 7. Калібр 75 - 60 г/га; 8. Калібр 75 - 70 г/га; 9. Калібр 75 - 30 г/га + Атат-25К + Агростимулін; 10. Калібр 75 - 40 г/га + Атат-25K + Агростимулін; 11. Калібр 75 - 50 г/га + Атгат-25K + Агростимулін; 12. Калібр 75 - 60 г/га + Атат-25K + Агростимулін; 13. Калібр 75 70 г/гa + Atam-25K + Агростимулін.

Відповідною реакцією рослинного організму на окиснювальний стрес є посилений синтез антиоксидантів - глутатіону, аскорбату та ін. Як показали результати досліджень, вміст глутатіону в листках ячменю ярого у варіантах досліду 3 сумісним застосуванням гербіцидів (Гранстар 75; Гранстар 75 + 2,4-ДА 500; Калібр 75) і рістрегуляторів (Емістим С, Агростимулін, Агат$25 K)$ збільшувався на 56-114 \%, що може бути пов'язано з безпосереднім стимулюючим впливом регуляторів росту рослин на синтез даного антиоксиданту та 3 меншою його витратою на ліквідацію активних форм кисню у результаті послаблення реакцій пероксидного окиснення ліпідів. Дещо нижчим вміст глутатіону був у варіантах досліду, де гербіциди застосовували без регуляторів росту, що свідчить про більш активну його витрату в реакціях, спрямованих як на детоксикацію ксенобіотика, так і в реакціях ліквідації активних форм кисню.

Щодо вмісту в рослинах ячменю ярого аскорбінової кислоти, то зі збільшенням норм використання досліджуваних гербіцидів iï вміст у листках на третю добу після внесення препаратів знижувався. Однак на десяту добу вміст аскорбінової кислоти в листках ячменю ярого значно

зростав як у варіантах із внесенням гербіцидів без регуляторів росту, так і в варіантах, де гербіциди вносили сумісно з рістрегуляторами, що може вказувати на стабілізацію детоксикаційних процесів у рослинах та підвищення їх антиокиснювальної активності (рис. 2).

Так, на прикладі гербіциду класу сульфонілсечовини Гранстар 75, внесеного в нормах 10; 15; 20 і 25 г/га, встановлено, що антиокиснювальна активність ячменю ярого на третю добу в порівнянні з контролем зростала на $10 ; 15 ; 13$ і $1 \%$ відповідно, однак за сумісного внесення цих же норм препарату з Емістимом С вона збільшувалася на $17 ; 20 ; 15$ і $6 \%$ відповідно.

На десяту добу внесення препаратів антиокиснювальна активність тканин листка ячменю ярого значно перевищувала контрольні показники у всіх варіантах досліду, але при цьому зберігалася закономірність: із наростанням норм внесення Гранстару 75 показник антиокиснювальної активності знижувався, хоча у порівнянні 3 контролем залишався високим; разом із тим у варіантах досліду, де Гранстар 75 вносили сумісно 3 Емістимом C, він перевищував аналогічні варіанти з внесенням гербіциду без рістрегуляторів. 


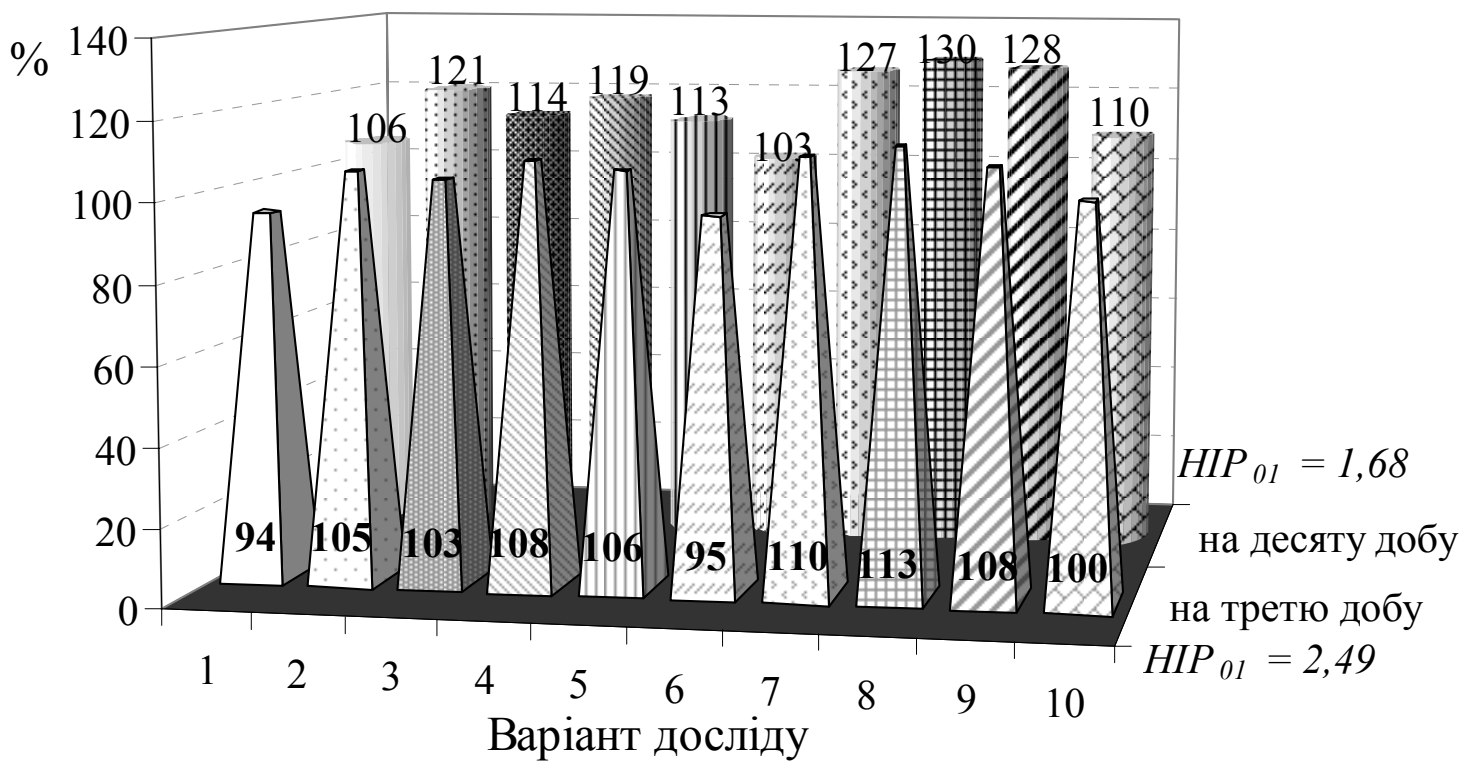

Рис. 2. Антиокиснювальна активність тканин листка ячменю ярого за дії різних норм гербіциду Гранстар 75, внесених окремо і в поєднанні з Емістимом С (вететаційний досліо, 2006 р.):

1. Обробка водою (контроль); 2. Емістим С; 3. Гранстар 75 - 10 г/2а; 4. Гранстар 75 - 15 г/2а; 5. Гранстар 75 - 20 г/2а; 6. Гранстар 75 - 25 г/2а; 7. Гранстар 75 - 10 г/2а + Емістим С; 8. Гранстар $75-$ 15 г/2а + Емістим С; 9. Гранстар $75-20$ г/га + Емістим C; 10. Гранстар $75-25$ г/2а + Емістим С.

Високий рівень антиокиснювальної активності тканин листка було відмічено також у варіантах із використанням бакових сумішей гербіцидів Гранстар 75 + 2,4-ДА $500+$ Емістим С і Калібр $75+$ Агат-25K + Агростимулін, які забезпечували зниження рівня пероксидного окиснення ліпідів у рослинах за одночасного зростання вмісту в листках антиоксидантних сполук. Між антиокиснювальною активністю тканин листка та вмістом у рослинах антиоксидантів встановлено пряму й сильну за тіснотою кореляційну залежність: $r=0,73$.

Під час вивчення впливу досліджуваних композицій на формування пігментного комплексу ячменю ярого встановлено, що оптимальні норми гербіцидів класів сульфонілсечовини (Гранстар 75 - 10-15 г/га, Калібр 75 - 40 г/га, Хармоні 75 - 15 г/га), феноксикарбоксилових кислот $(2,4-$ ДА $500-1,0$ л/га, Дікопур Ф $600-0,5$ л/га), комбінованих препаратів (Лінтур 70WG 100 г/га), внесені з регуляторами росту рослин (Емістим С, Агростимулін, Агат-25K), забезпечували формування відносно високого рівня суми хлорофілів $a$ і $в$ у листках ячменю ярого (в порівнянні 3 контролем у середньому на 15$62 \%)$ та більшого за розмірами світлозбирального комплексу (СЗК) (на 13-17\%). У той же час підвищені норми застосування гербіцидів, особливо сульфонілсечовин у сумішах із фен- оксикарбоксиловими кислотами (Гранстар 75 20-25 г/га + 2,4-ДА $500-1,0$ л/га), негативно впливали на формування пігментного комплексу рослин, що може бути обумовлено безпосередньою дією цих препаратів як на процеси синтезу хлорофілу, так і його руйнування (див. табл.). Адже відомо, що гербіциди можуть стимулювати гідролітичну активність ферменту хлорофілази, яка зазвичай перебуває у зв'язаному стані 3 білками та іншими речовинами мембран у найбільш асоційованій формі з невеликою активністю. Однак у процесі детоксикації гербіцидів у хлоропластах може порушуватися стабільність хлорофіл-білково-ліпоїдного комплексу, що призводить до активізації ферменту. Так, встановлено, що за використання Гранстару 75 20-25 г/га окремо і в сумішах із регулятором росту Емістим C активність хлорофілази в листках ячменю зростала в середньому по відношенню до контролю на $17-42 \%$.

Залежно від дії досліджуваних препаратів на пігментний комплекс рослин ячменю ярого, відповідні зміни простежувались у проходженні фотосинтетичних процесів, які нерозривно пов'язані 3 асиміляцією вуглецевих сполук. Встановлено, що нагромадження водорозчинних цукрів у листках ячменю ярого у фазу виходу рослин у трубку зростало за інтегрованого застосування гербіцидів і регуляторів росту, що $є$ 
проявом безпосереднього позитивного впливу рістрегуляторів на обмінні процеси в рослинному організмі, які тісно пов'язані з генним та гормональним рівнем регуляції. Так, на прикладі гербіциду групи комбінованих препаратів Лінтур 70WG, внесеного у нормах 90; 100; 120 i 140 г/га окремо і в поєднанні 3 Агатом-25К, встановлено, що нагромадження цукрів найбільш активно відбувалось у варіантах з інтегрованим застосуванням препаратів, що у фазу виходу рослин у трубку в 2005 р. перевищувало контроль I на 24; 39; 25 і 7 \% відповідно, а в фазу виколошування - на 28; 48; 32 і $17 \%$ (рис. 3 ). Найбільш інтенсивне нагромадження рослинами ячменю ярого цукрів забезпечувала бакова суміш Лінтур 70WG 100 г/га + Агат-25К, що підтверджується найвищою активністю проходження фізіолого-біохімічних процесів у даному варіанті досліду.

Водночас, слід зауважити, що у фазу виколошування ячменю ярого вміст цукрів у листках рослин у всіх варіантах досліду, де гербіцид вносили окремо і в поєднанні з регулятором росту, значно перевищував контроль I, але в порівнянні до показників у фазу виходу рослин у трубку був нижчим. Це свідчить про залежність нагромадження цукрів листками ячменю ярого від фази розвитку рослин, максимум за вмістом яких приходиться на IV етап органогенезу (вихід у трубку), тобто, на періоди мікро- і макроспорогенезу. Крім того, у фазу виколошування асимільований листками ячменю ярого вуглець активно транспортується в стебло, а звідти - у колос, де й відмічається його максимальна кількість.

Нагромадження рослинами ячменю ярого вуглецевих сполук проходило в тісній кореляційній залежності $(\mathrm{r}=0,79-0,87)$ із фотосинтетичною продуктивністю посівів (ФПП), найвищі значення якої формувались за використання в посівах композицій: Калібр 7540 г/га + Агат-25К + Агростимулін; Гранстар 7515 г/га + Емістим C; Гранстар 7510 г/га + 2,4-ДА 500 1,0 л/га + Емістим С; Дікопур Ф 600 0,5 л/га + Гранстар 75 15 г/га + Емістим С; Лінтур 70 WG 100 г/га + Агат-25К та Хармоні 7515 г/га + Агат-25К.

Вміст і співвідношення пітментів у листках ячменю ярого за обробки баковими сумішами гербіциду класу сульфонілсечовини Гранстар 75 і гербіциду класу феноксикарбоксилових кислот 2,4-ДА 500, внесених окремо і в поєднанні з Емістимом С (фаза трьох листків, шоста доба після застосування препаратів, вететаційний досліб, 2008 р.), мг/2 сирої маси

\begin{tabular}{|c|c|c|c|c|c|c|}
\hline Варіант досліду & Хл & $\mathrm{X}_{\mathrm{b}}$ & Хл $(\mathrm{a}+\mathrm{b})$ & 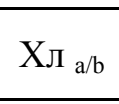 & $\begin{array}{c}\text { Сума } \\
\text { каротиноїдів } \\
\end{array}$ & СЗК, \% \\
\hline $\begin{array}{c}\text { Обробка водою } \\
\text { (контроль) }\end{array}$ & 0,540 & 0,180 & 0,720 & 3,0 & 0,140 & 55 \\
\hline Емістим C & 0,551 & 0,196 & 0,747 & 2,8 & 0,158 & 58 \\
\hline $\begin{array}{c}\text { Гранстар } 7510 \text { г/га + } \\
\text { 2,4-ДА } 500 \text { 1,0 л/га }\end{array}$ & 0,596 & 0,213 & 0,809 & 2,8 & 0,161 & 58 \\
\hline 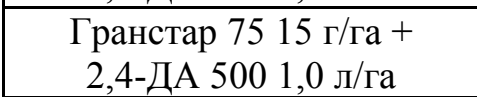 & 0,559 & 0,193 & 0,752 & 2,9 & 0,183 & 56 \\
\hline 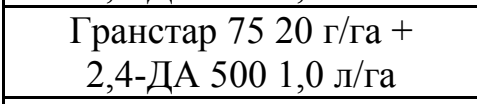 & 0,523 & 0,154 & 0,677 & 3,4 & 0,134 & 50 \\
\hline 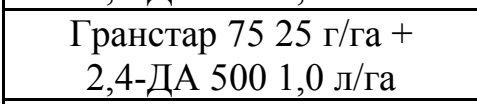 & 0,514 & 0,143 & 0,657 & 3,6 & 0,128 & 48 \\
\hline $\begin{array}{c}\text { Гранстар } 7510 \text { г/га + 2,4- } \\
\text { ДА } 5001,0 \text { л/га + Емістим С }\end{array}$ & 0,686 & 0,264 & 0,950 & 2,6 & 0,193 & 62 \\
\hline $\begin{array}{c}\text { Гранстар } 7515 \text { г/га + 2,4- } \\
\text { ДА } 5001,0 \text { л/га + Емістим С }\end{array}$ & 0,630 & 0,210 & 0,840 & 3,0 & 0,190 & 55 \\
\hline $\begin{array}{c}\text { Гранстар } 7520 \text { г/га + 2,4- } \\
\text { ДА } 5001,0 \text { л/га + Емістим С }\end{array}$ & 0,535 & 0,160 & 0,695 & 3,3 & 0,136 & 50 \\
\hline \begin{tabular}{|c|} 
Гранстар 7525 г/га + 2,4- \\
ДА 5001,0 л/га + Емістим С \\
\end{tabular} & 0,526 & 0,145 & 0,671 & 3,6 & 0,130 & 48 \\
\hline$H I P_{01}$ & 0,036 & 0,013 & 0,051 & - & 0,015 & - \\
\hline
\end{tabular}



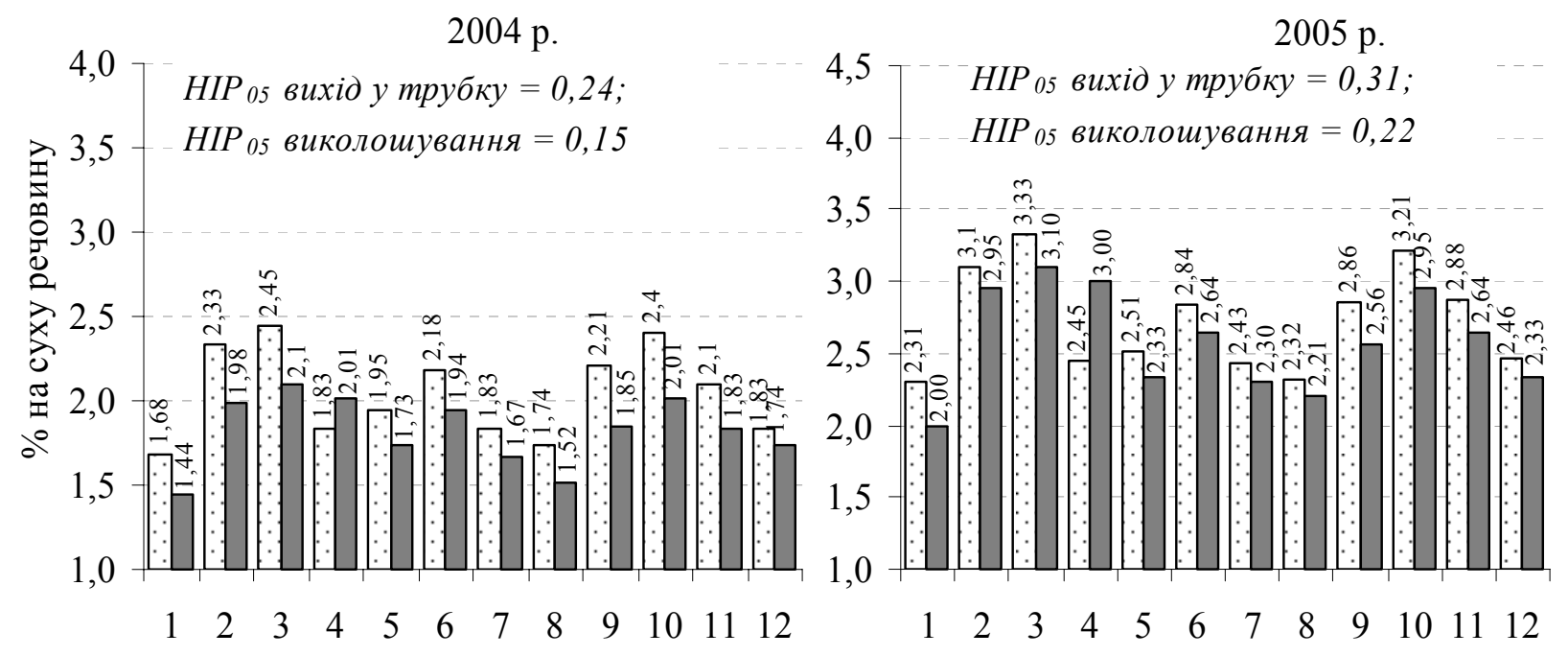

Рис. 3. Вміст суми водорозчинних иукрів у листках ячменю ярого за дії різних норм гербіциду групи комбінованих препаратів Лінтур 70WG, внесених роздільно і в сумішах із Агатом-25K:

\section{$\square$ - вихід у трубку; $\square$ - виколошування}

1. Без застосування препаратів (контроль I); 2. Ручні прополювання впродовж вететачійного періоду (контроль II); 3. Ручні прополювання впродовж вететаційного періоду + Atат-25K (контроль III); 4. Атат-25K; 5. Лінтур 70WG 90 г/га; 6. Лінтур 70WG 100 г/га; 7. Лінтур 70WG 120 г/га; 8. Лінтур 70WG 140 г/га; 9. Лінтур 70WG 90 г/гa + Atam-25K; 10. Лінтур 70WG 100 г/2a + Atam-25K; 11. Лінтур 70WG 120 г/2a + Aтат-25K; 12. Лінтур 70WG 140 г/гa + Atam-25K.

Так, упродовж 1999-2009 рр. вищезазначені суміші забезпечили зростання ФПП у середньому на 40-80 \%, фотосинтетичної продуктивності хлорофілу - 30-132\%, що обумовлювалося загальним позитивним впливом даних композицій на проходження у рослинах фізіологобіохімічних процесів на фоні мінімального конкурентного впливу на культуру бур'янів.

\section{Висновки:}

1. Гербіциди класу сульфонілсечовини (Гранстар 75, Калібр 75) і феноксикарбоксилових кислот (2,4-ДА 500, Дікопур Ф 600), внесені окремо та в поєднанні з рістрегуляторами (Емістим С, Агат-25К і Агростимулін), визначають спрямованість перебігу реакцій пероксидного окиснення ліпідів у рослинах ячменю ярого, проходження яких значно гальмується за інтегрованого їх застосування із регуляторами росту рослин. Це супроводжується зростанням на третю добу у рослинах вмісту низькомолекулярних антиоксидантів - глутатіону (56-114\%) i аскорбату (7-26\%) та загальним підвищенням антиокиснювальної активності тканин (6-22\%).

2. За підвищених норм застосування гербіцидів класу сульфонілсечовини (Гранстар 75) та їх бакових сумішей із гербіцидами класу феноксикарбоксилових кислот (2,4-ДА 500, Дікопур Ф 600) у лис- тках ячменю ярого простежується зниження вмісту хлорофілів $a$ і $b$ та їх суми (2-21\%), що $\epsilon$ наслідком гальмування під дією гербіцидів синтезу хлорофілів або ж їх руйнування ферментом хлорофілазою, активність якої при цьому зростає в середньому на 4-42\%.

3 . Найвища фотосинтетична активність ячменю ярого простежується за використання в посівах бакових сумішей Калібр 7540 г/га + Агат$25 \mathrm{~K}+$ Агростимулін; Гранстар 7515 г/га + Емістим C; Гранстар 7510 г/га + 2,4-ДА 500 1,0 л/га + Емістим С; Дікопур Ф 600 0,5 л/га + Гранстар 7515 г/га + Емістим C; Лінтур 70 WG 100 г/га + Агат-25К та Хармоні 7515 г/га + Агат-25К, які забезпечують зростання рівня ФПП близько $80 \%$.

4. Виконані фізіолого-біохімічні дослідження інтегрованої дії препаратів у посівах ячменю ярого дають підставу стверджувати, що регулятори росту рослин за сумісного їхнього внесення 3 гербіцидами сприяють активізації роботи антиоксидантних систем захисту рослинного організму, завдяки яким негативний вплив на клітини продуктів метаболізму ксенобіотиків значно знижується, а фотосинтетична й загальна продуктивність рослин при цьому підвищуються. 


\section{БІБЛІОГРАФІЯ}

1. Борона В. П. Гербологія: проблеми розвитку // В. П. Борона, В. С. Задорожний // Захист рослин. 2003. - № 11. - C. 21-22.

2. Гавриленко В. Ф. Большой практикум по фотосинтезу / В. Ф. Гавриленко, Т. В. Жигалова; под. ред. И. П. Ермакова. - М. : Академия, 2003. $-256 \mathrm{c}$.

3. Грищаєнко 3. М. Методи біологічних та агрохімічних досліджень рослин і грунтів / Грицаєнко 3. М., Грицаєнко А. О., Карпенко В. П. - К. : ЗАТ «Нічлава», 2003. $-320 \mathrm{c.}$

4. Гришко В. Н. Метод определения восстановленной формы глутатиона в вегетативных органах растений / В. Н. Гришко, Д. В. Сыщиков // Укр. біохім. журнал. - 2002. - Т. 74. - № 415. C. $123-124$.

5. Дорохов Л. М. Минеральное питание как фактор повышения фотосинтеза и урожая сельскохозяйственных растений / Л. М. Дорохов // Труды Кишиневского СХИ. - Кишинев, 1957. С. $70-100$.

6. Доспехов Б. А. Методика полевого опыта с основами статистической обработки результатов исследований / Доспехов Б. А. - М. : Агропромиздат, 1985. - $351 \mathrm{c}$.

7. Жеребко В. М. Гербіциди в інтегрованому захисті / В. М. Жеребко // Карантин і захист рослин. - 2007. - № 7. - С. 12-13.

8. Журбицкий 3. И. Теория и практика вегетационного метода / Журбицкий 3. И. - М. : Наука, 1986. -268 c.

9. Мережинський Ю. Г. Сучасні досягнення та перспективи розвитку досліджень по проблемі фізіології дії гербіцидів / Ю. Г. Мережинський, Є. Ю. Мордерер // Фізіологія рослин в Україні на межі тисячоліть. - К., 2001. - Т. 1. - С. 345-361.
10. Методики випробування і застосування пестицидів / [Трибель С. О., Сігарьова Д. Д., Секун М. П. та ін.]. - К. : Світ, 2001. - 448 с.

11. Мордерер С. Ю. Гербіциди. Механізми дії та практика застосування / Є. Ю. Мордерер, Ю. Г. Мережинський. - К. : Логос, 2009. - 379 с.

12. Ничипорович A. А. Фотосинтез и вопросы продуктивности растений / А. А. Ничипорович. М. : Наука, 1963. - С. 5-36.

13. Пономаренко С. П. Новые индукторы устойчивости растений с регуляторными и биозащитными свойствами / С. П. Пономаренко, Г. С. Боровикова, Ю. Я. Боровиков // Материалы $\mathrm{V}$ Межд. науч. конф. [«Регуляция роста, развития и продуктивности растений»], (Минск, 28-30 ноября 2007) / Институт экспериментальной ботаники НАН Беларуси. - Минск : Право и экономика, 2007. - С. 161.

14. Райов A. А. Формирование урожая и качество зерна пивоваренного ячменя при применении стимуляторов роста и средств защиты растений в Оренбургском Предуралье: автореферат дис. на соискание науч. степени канд. с.-х. наук : спец. 06.01 .09 «Растениеводство» / А. А. Райов. Оренбург, 2004. - 18 c.

15. Рогожин B. B. Практикум по биологической химии / В. В. Рогожин. - СПб. : Лань, 2006. C. $132-134$.

16. Сульфонилмочевины в России // Защита и карантин растений. - 2004. - № 2. - С. 42.

17. Терек O. I. Ріст рослин / О. І. Терек. - Львів : Видавничий центр ЛНУ ім. І. Франка, 2007. $248 \mathrm{c}$.

18. Чупахина Г. Н. Физиологические и биохимические методы анализа растений / Чупахина Г. Н. Калининград, 2000. - С. 7-9. 